\title{
Delay and cost overrun in road construction projects in Jordan
}

\author{
Nabil Al-Hazim ${ }^{1 *}$, Zaydoun Abu Salem ${ }^{2}$ \\ ${ }^{1}$ Department of civil Engineering, Al-Ahliyya Amman University Jordan \\ ${ }^{2}$ Department of Civil Engineering and Infrastructure, Al Zaytoonah University Jordan \\ *Corresponding author E-mail: nabilhazim61@gmail.com
}

Copyright $\odot 2015$ Nabil Al-Hazim, Zaydoun Abu Salem. This is an open access article distributed under the Creative Commons Attribution License, which permits unrestricted use, distribution, and reproduction in any medium, provided the original work is properly cited.

\begin{abstract}
This study aims to identify the most important factors that cause delay in road construction projects in Jordan, which results in cost and time overrun allocated for this type of engineering projects and cause critical problems for both the developer and the contractor. The gap between the cost at completion and that originally estimated, known as cost overrun, can be regarded as one of the most important parameters reflecting the success of projects. In the public sector, money spent on project change orders results in increased construction time which in return reduces the number and size of the projects that can be completed during any given fiscal year. To achieve this goal, the documents and the final reports for several sample projects implemented over the years 2000 to 2008 were analyzed. All the projects were administered by the same organization taken from Jordan Ministry of Rural and Public Works. The results of this study can assist highway officials in their design, planning, scheduling and projects completions so that necessary actions can be taken to control these overruns in future projects. The study showed that 19 factors might cause delays of road construction projects as defined through a detailed literature review. The analysis of the study indicated that the top causes affecting time and cost overrun in road construction projects in Jordan are Terrain and Weather conditions.
\end{abstract}

Keywords: Project Management; Road Construction; Cost Overrun; Civil Engineering.

\section{Introduction}

A cost overrun is defined as a cost increase or budget overrun, involves unexpected cost incurred in excess of the budget amount due to an underestimation of the actual cost budgeting of the road construction projects of the most important projects in Jordan. These projects needed to connect cities and to serve the movement of people and goods. Most road construction projects in Jordan are characterized by overrun in cost and time. Problem of cost overrun is critical and needs to be studied to alleviate this problem in the future and to make recommendations to overcome the critical factors in future road projects.

Generally, cost overruns to have several reasons [1]: errors in budgeting, costs required beyond the scope of work, tools and equipment costs exceed project allocation.

For this reason, we conduct the analyses and examination of the repots taken from the Jordanian Ministry of Rural and Public Works for several road projects in Jordan over the years 2000-2008. The causes for cost and time overrun in these projects in this study were the actual causes that happen. Ranks of the factors were identified based on their significance and identify the critical factors influencing cost and time overrun.

\section{Literature review}

We did not find any study pertaining to the subject of cost overrun and time delay in the implementation of road construction projects in Jordan, and on the other hand, there is some research in other countries, which focused on this topic. S.M. Vidalis [2] found that the factors causing coast and time overrun in highway construction are plans modifications, changed conditions and lack of project coordination. 
Mahamid [3] found that from the field, survey included 40 consultants, the top five affecting factors from consultants view are materials price fluctuation, size of contract and incomplete drawings. He stated that $100 \%$ of projects suffering from cost diverge, also he found that $76.33 \%$ of projects have cost over estimation while $23.67 \%$ have cost underestimation, and the discrepancy between actual cost and estimated cost has an average of $14.56 \%$.

From 41 factors considered in the study, Alhomidan [4] stated that the most severe factors affecting cost overrun in road construction projects are internal administrative problems, payment delay and poor delays in decision making. He indicates that among a risk map of 41 factors considered in a survey, the most factors affecting cost overrun in road construction projects in Saudi Arabia from contractors' viewpoint are: internal administrative problems, payments delay, poor communication between construction parties, and delays in decision making.

Adnan Enshassi [5] recommended to develop human resources in the construction through continuous training programs about construction projects. In addition, consultants should be more interested in design cost and are urged to facilate and expedite orders delivered to contractors to obtain better time performance and to minimize disputes and claims. James Odeck [6] using data from Norwegian road construction projects over the years 1992-1995 found that the discrepancy between estimated and actual cost with a mean cost overrun of $7.9 \%$ ranging from $5.9 \%$ to $183 \%$.

Many studies have been conducted to identify the causes of delay in construction projects. Chan et al. [7] indicated that the five principal causes of delays in Hong Kong construction projects are poor site management and supervision, unforeseen ground conditions, low speed of decision making involving all project teams, client-initiated variations and necessary variations of works.

Examining the factors that cause delay in construction projects in Malaysia, Alghbari et al. [8] tested 31 variables. The main finding of the study was that financial factors are the most common cause of delays in construction projects in Malaysia. Coordination problems are considered the second most important factor causing delays, followed by materials problems. Al-Momani [9] investigated causes of delay in 130 public building projects constructed in Jordan during the period of 1990-1997. He concluded that the main causes of delay are related to designer or user changes, weather, site conditions, late deliveries, economic conditions and increases in quantities.

Sambasivan and Soon [10] concluded that the ten most important causes of delays in the construction industry in Malaysia were: contractor's improper planning, contractor's poor site management, inadequate contractor experience, inadequate client's finance and payments for completed work, problems with subcontractors, shortage in material, labor shortages, equipment availability and failure, lack of communication between parties, and mistakes during the construction stage.

Mahamid [11] indicated that the top risks affecting time overrun in road construction projects in Palestine are: financial status of the contractors, payment delays by the owner, the political situation and segmentation of the West Bank, poor communication between construction parties, lack of equipment efficiency and high competition in bids.

Wijekoon et al, [12] concluded in a questionnaire survey that the critical factors influencing cost overrun at preconstruction and construction phases of road projects in SriLanka are delays in making payment, delays due to utility relocation. Design changes during construction phase, cost escalation and land acquisition related issues. Roachanakanan, [13] indicate that the critical factors influencing cost overrun are unpredictable weather, inflationary material costs, inaccurate material estimates, project complexity, lack of information about the site geography. Lack of contractors experience on a certain type of projects, and unfamiliarity with local regulations.

\section{Research methodology}

About 19 major causes were identified as causes of cost and time overrun through literature, orders from the owner, and discussion with parties in the road construction sector in more than 25 major projects in Jordan in the period of 2000 2008. These causes were the actual causes that been documented through paper work between the owner and the contractor. The most important reason that led to cost, and time overrun was terrain conditions that has $21.9 \%$ in ranking. These conditions include difficulties in reaching the work site, difficulties the work type, land acquisition issues, delay in relocating utilities, and the lack of civil services near the work site which were not included within the work plan and cost studies.

The second main reason in cost and time overrun was weather conditions that has $15.5 \%$ in ranking. Those two reasons were the main reasons that led to additional reasons that cause cost and time overrun such as new variation orders $(9.1 \%$ in ranking), costs of variation orders ( $2 \%$ in ranking), mistakes in design $(7.1 \%$ in ranking), emergency working ( $3.5 \%$ in ranking), planned time for project construction (4.4 in ranking), and planned to cost for project construction (6.9\% in ranking) that needed to make up with the new conditions due to terrain and weather conditions.

\section{Results and discussion}

Table 1 shows the ranking for each factor arranged according to their importance while Figure 1 shows the graphical representation. 
Table 1: Factors Ranking Arranged According to Their Importance.

\begin{tabular}{ll}
\hline Factors & Rank \\
\hline 1. Terrain conditions & $21.9 \%$ \\
2. Weather conditions & $15.5 \%$ \\
3. Variation orders & $9.1 \%$ \\
4. Availability of labor & $8.1 \%$ \\
5. Mistakes in design & $7.1 \%$ \\
6. Planned cost for project construction & $6.9 \%$ \\
7. Market conditions (availability of resources) & $5.6 \%$ \\
8. Material price fluctuations & $4.5 \%$ \\
9. Planned time for project construction & $4.4 \%$ \\
10. Emergency works & $3.5 \%$ \\
11. quality of equipment and raw materials & $2.3 \%$ \\
12. Payment delay & $2.1 \%$ \\
13. Cost of variation orders & $2 \%$ \\
14. Political situation & $1.9 \%$ \\
15. Government requirements & $1.2 \%$ \\
16. Rework from poor materials quality & $1.2 \%$ \\
17. Delay in decision & $1.1 \%$ \\
18. Management - labor relationship & $0.9 \%$ \\
19. Sequencing of work according to schedule & $0.7 \%$ \\
\hline
\end{tabular}

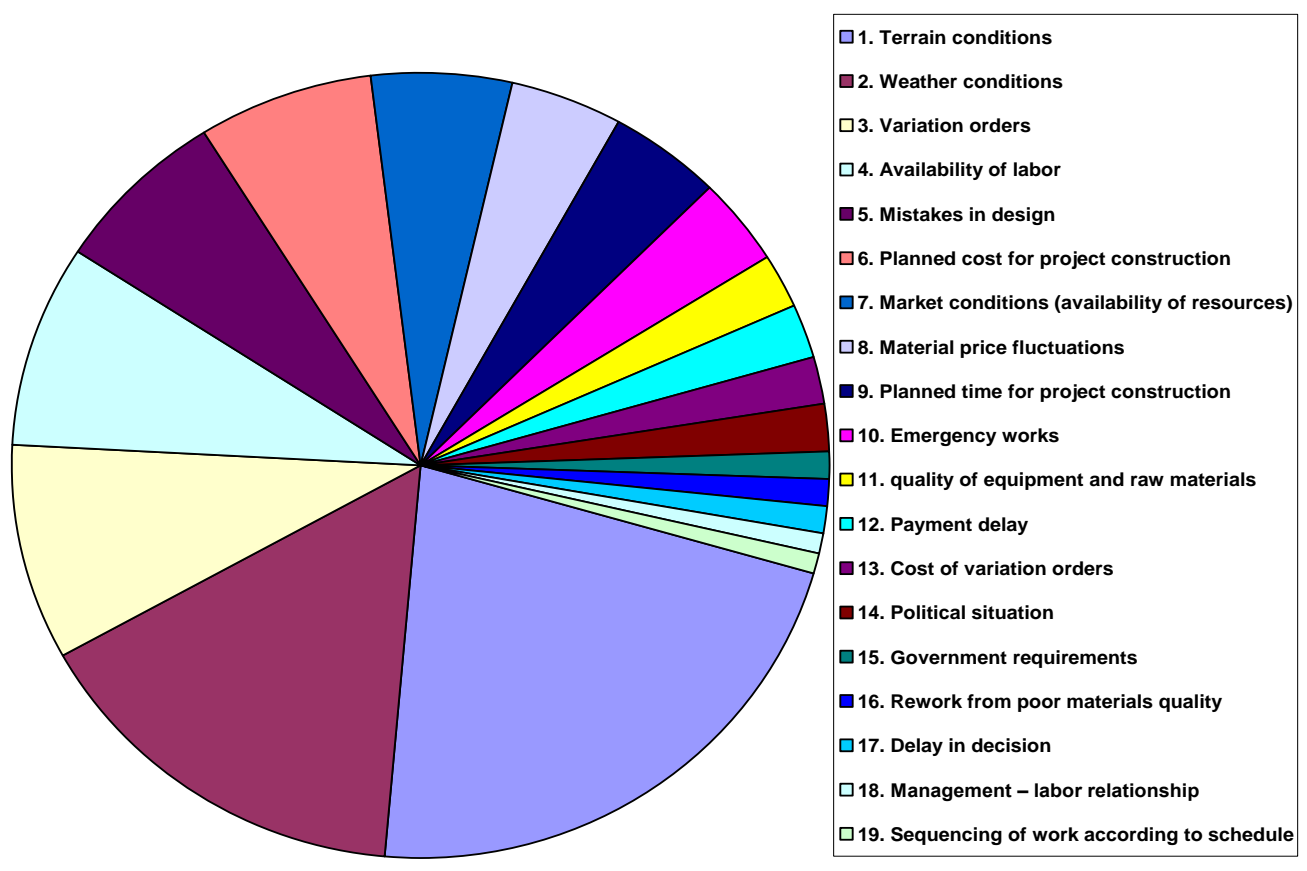

Fig. 1: Factors Ranking Arranged According to Their Importance.

Table 2 shows the planned - actual time and cost for 9 sample projects. The average percentage overrun time is 226 and the average percentage overrun cost is 214 .

Table 2: Planned and Actual Time and Cost for 9 Sample Projects

\begin{tabular}{lllllll}
\hline Project \# & $\begin{array}{l}\text { Time planned } \\
\text { (day) }\end{array}$ & $\begin{array}{l}\text { Time (actual) } \\
\text { (day) }\end{array}$ & Time overrun \% & $\begin{array}{l}\text { Cost planned } \\
\text { (JD) }\end{array}$ & $\begin{array}{l}\text { Cost actual } \\
\text { (JD) }\end{array}$ & $\begin{array}{l}\text { Cost overrun } \\
\%\end{array}$ \\
\hline 1 & 730 & 914 & 125 & 5069475 & 7687652 & 150 \\
2 & 120 & 255 & 213 & 1998090 & 1991719 & 101 \\
3 & 75 & 193 & 257 & 189010 & 199101 & 105 \\
4 & 300 & 735 & 245 & 44990 & 284537 & 600 \\
5 & 1500 & 683 & 455 & 483226 & 1070629 & 221 \\
6 & 365 & 789 & 19624 & 8316524 & 355 \\
7 & 900 & 1729 & 188 & 2340525 & 14561283 & 146 \\
8 & 1000 & 1879 & 147 & 12124023 & 14829575 & 122 \\
9 & 800 & 1470 & & 6391068 & 7950420 & 124 \\
\hline
\end{tabular}


Figure 2 shows the planned and actual time for the sample projects.

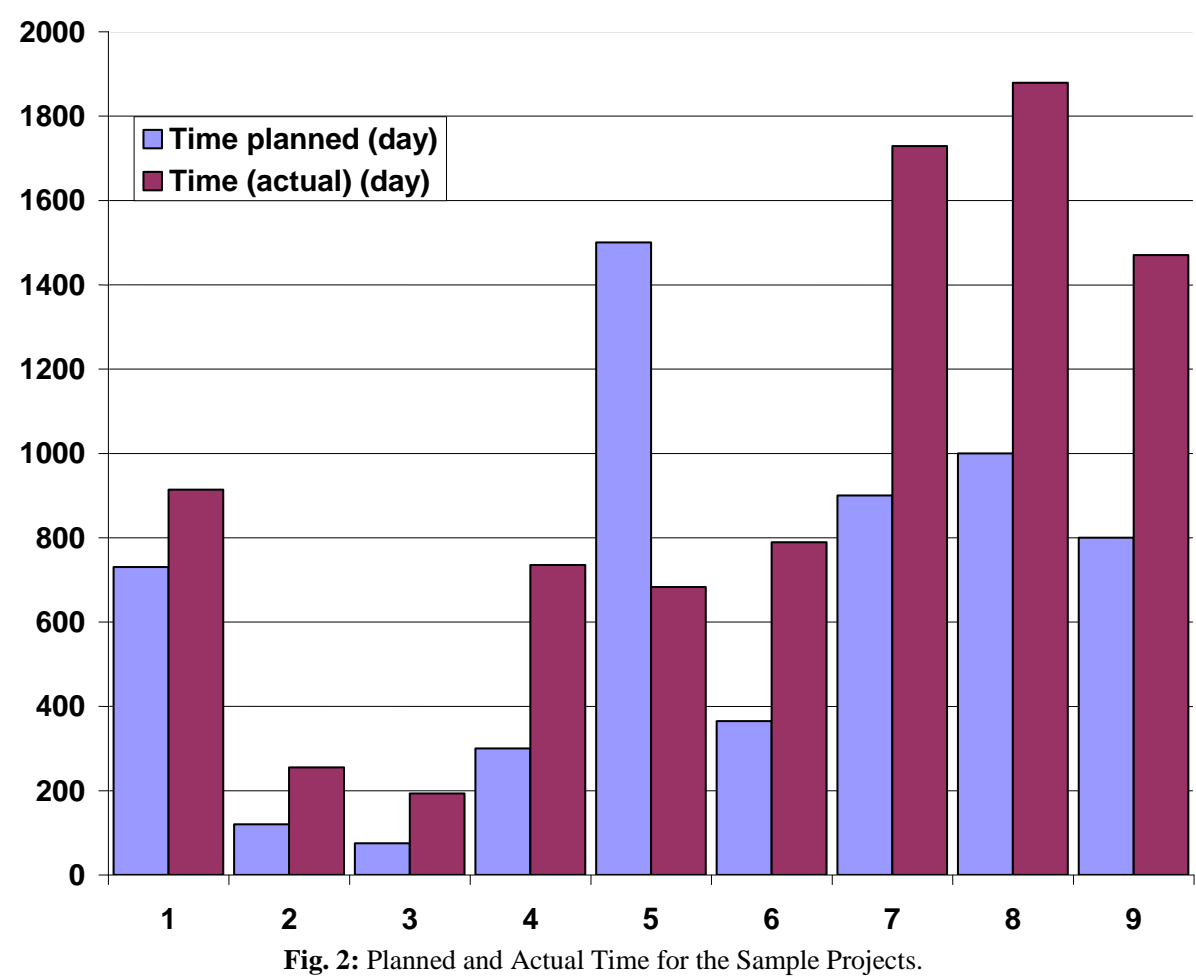

Figure 3 shows the planned and actual cost for the sample projects.

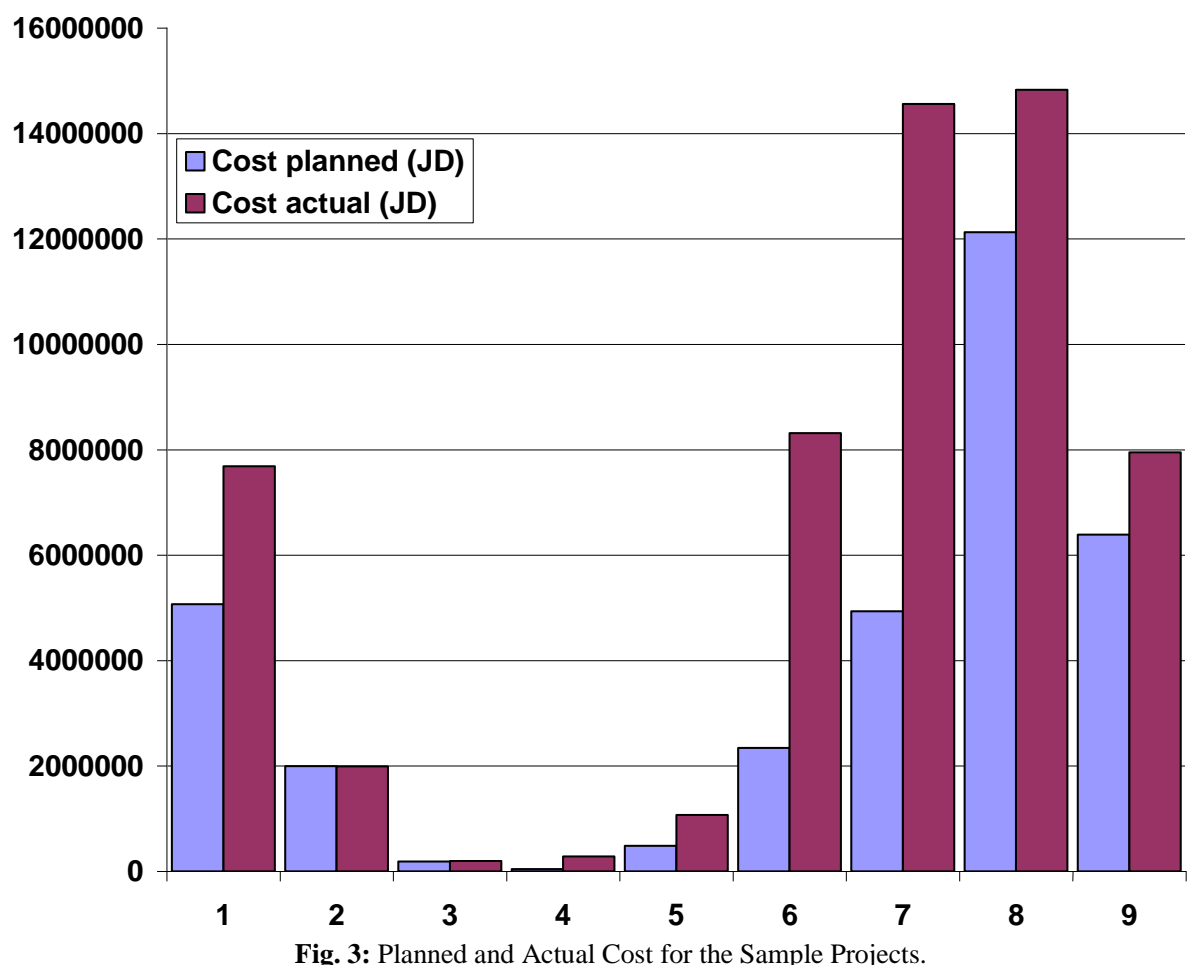

Figure 4 shows the cost overrun for the sample projects. 


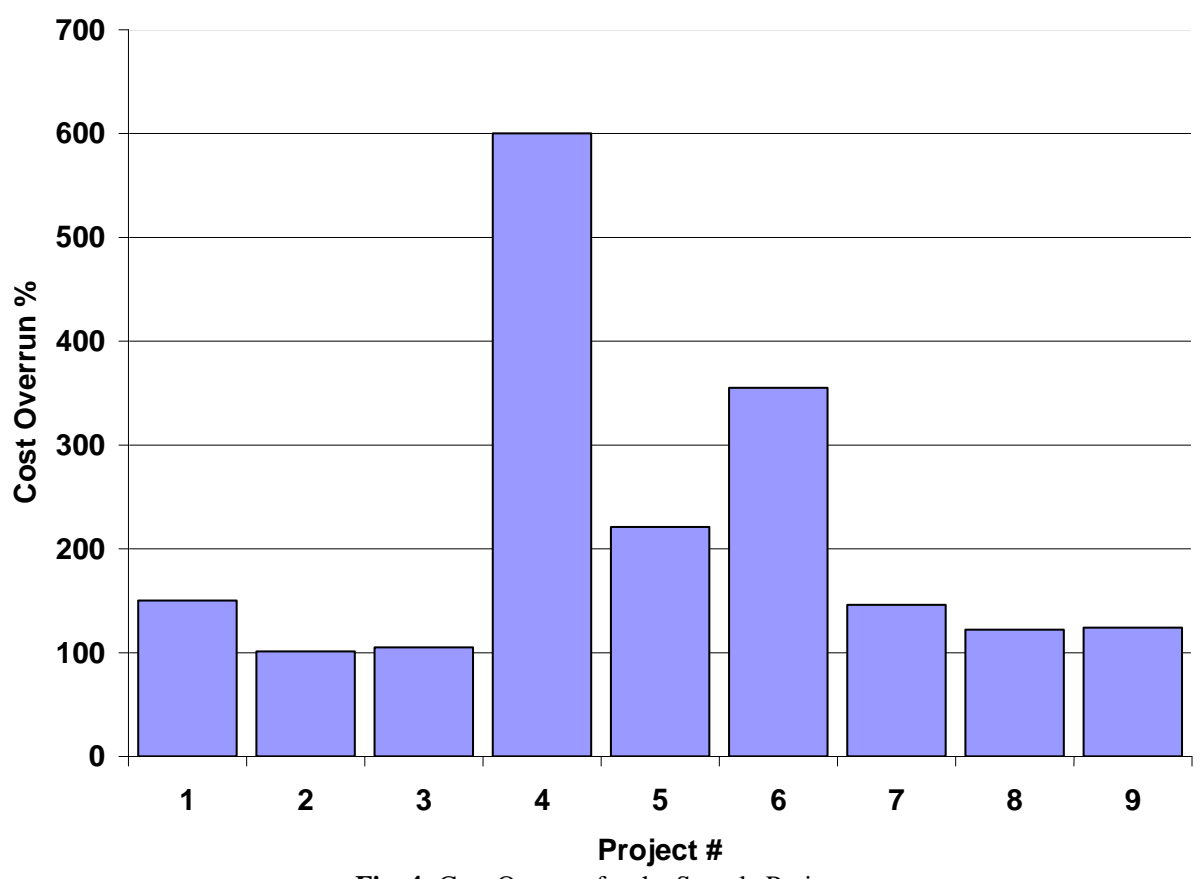

Fig. 4: Cost Overrun for the Sample Projects.

Figure 5 shows the time overrun for the sample projects.

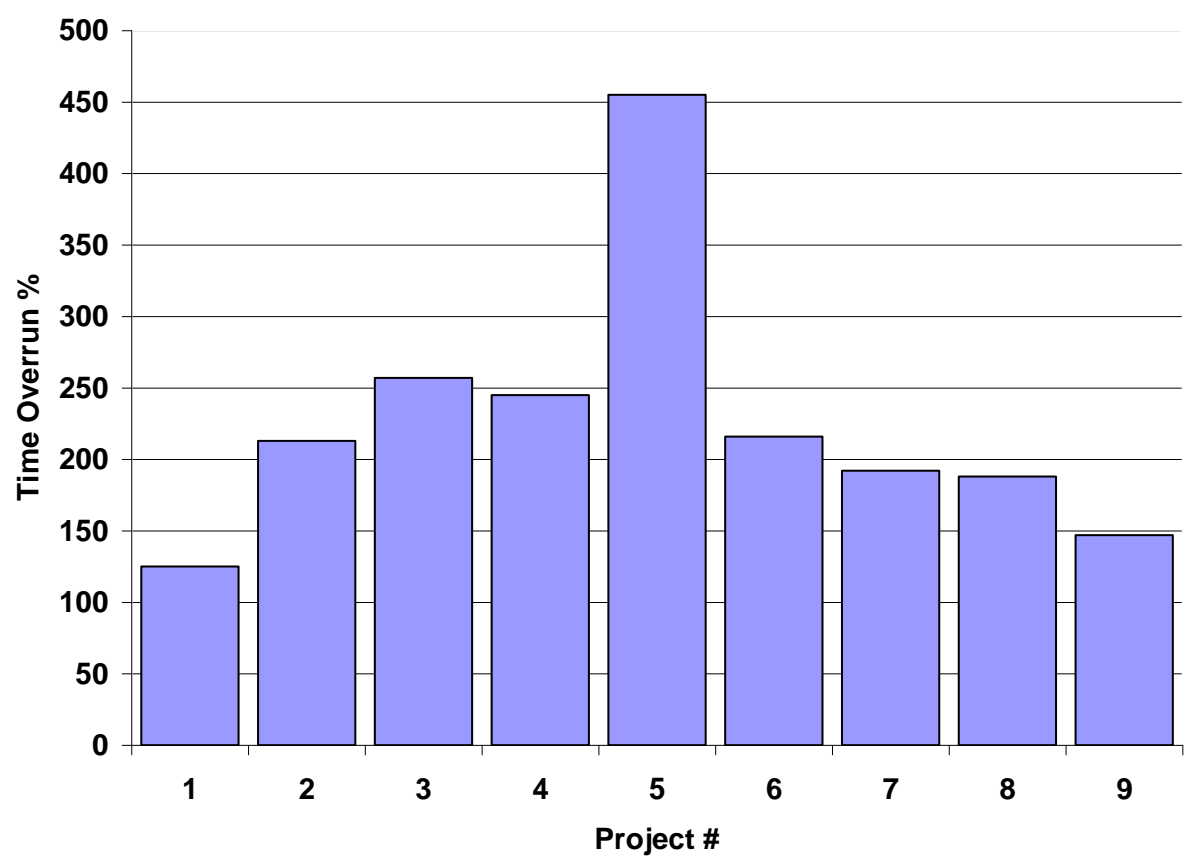

Fig. 5: Time Overrun for the Sample Projects.

\section{Conclusions}

Most road construction projects in Jordan are characterized by delay and overrun in cost. Many documents and final reports for several projects were analyzed. The results show that most of the critical factors are: Terrain conditions, weather conditions, variation of order, and availability of labor.

A very big discrepancy between estimated and final cost ranging from $101 \%$ to $600 \%$ with an average of $214 \%$. On the other hand, the delay time ranging from $125 \%$ to $455 \%$ with an average of $226 \%$.

In order to validate these findings, further research is recommended with projects from different geographical locations and owners. Moreover, it is recommended that other factors should have to be identified that contribute to construction cost, and schedule overruns in public work projects. 


\section{References}

[1] Gary Hinson, "Cost overrun in construction, reasons and solutions," construction Business owner, July 1/2009.

[2] S. M. Vidalis, "Cost and time overrun in highway construction," 4th transportation specialty conference of the Canadian society for civil engineering, Canada 5/8 June 2002.

[3] Ibrahim Mahamid, "cost overrun causes in road construction projects-consultants perspective," 2nd International conference on construction and project management, IPEDR, Vol 15, Singapore. 2011.

[4] Abdullah Alhomidan, "factors affecting cost overrun in road construction projects in Saudi Arabia," International Journal of Civil \& Environmental Engineering, IJEE-IJENS Vol: 13 No:3. 2010.

[5] Adnan Enshassi, "Factors affecting the performance of construction projects in the Gaza Strip," Journal of Engineering and Management, 15(3): 269-280. 2009. http://dx.doi.org/10.3846/1392-3730.2009.15.269-280.

[6] James Odeck, "Cost overrun in road construction - what are their sizes and determinants," Transport policy, Vol. 11, Issue 1, Pages 43-53. 2004. http://dx.doi.org/10.1016/S0967-070X(03)00017-9.

[7] Chan, Daniel W. and Kumaraswamy, Mohan M. "A comparative study of causes of time overruns in Hong Kong construction projects," International Journal of Project Management, 15 (1), 55-63. 1997. http://dx.doi.org/10.1016/S0263-7863(96)00039-7.

[8] Alghbari, W., Kadir, M., Salim, A. and Ernawati, "The significant factors causing delay of building construction projects in Malaysia," Journal of Engineering, Construction and Architectural Management, 14 (2), 192-206. 2007. http://dx.doi.org/10.1108/09699980710731308.

[9] Al-Momani, A., "Construction delay: a quantitative analysis," International Journal of Project Management, 18 (1), 51-59. 2000. http://dx.doi.org/10.1016/S0263-7863(98)00060-X.

[10] Sambasivan, M. and Soon, Y., "Causes and effects of delays in Malaysian construction industry" International Journal of Project Management, 25 (5), 517-526. 2007. http://dx.doi.org/10.1016/j.ijproman.2006.11.007.

[11] Ibrahim Mahamid, "Common Risks Affecting Time Overrun in Road Construction Projects in Palestine: Contractors' Perspective," Journal of Construction Engineering, Volume 2013, Article ID 935978, 9 pages. 2013.

[12] Eng. S.B. Wijekoon, Eng. A.M.C.T.K. Attanayake, "Study on the Cost Overruns in Road Construction Projects in Sirlanka". 2005.

[13] Roachanakanan, K., "A case study of cost overruns in a Thai condominium Project" Texas: A\&M University.5-7, 33-35. 2005. 